\title{
Comparative performance of mini tractor drawn tillage implements for seed bed preparation under sandy loam conditions of middle Gujarat
}

K.L. DABHI, R.S. GODHANI AND R. SWARNKAR

Received : 20.02.2016; Revised : 28.02.2016; Accepted : 13.03 .2016

See end of the Paper for authors' affiliation

Correspondence to :

\section{K.L. DABHI}

Department of Farm Machinery Power Engineering, College of Agricultural Engineering and Technology, Anand Agricultural University, GODHRA (GUJARAT) INDIA Email : kldabhi876@gmail.com
-ABSTRACT : Tillage is an operation performed to obtain a desirable soil structure for a seedbed or rootbed. Reducing tillage operations is a way of saving money and labour, but there are other factors which need to be considered before adopting a particular technique. Field tests were conducted to evaluate the performance of three types of mini tractor drawn tillage implements for seedbed preparation at College of Agricultural Engineering and Technology, Anand Agricultural University Godhra, district: Panchmahal. The mini tractor, Mahindra-Yuvraj (15 hp) and the matching tillage impalements i.e. cultivator, M.B. plough and rotavator were used for seedbed preparation by selecting four different treatments, namely; $\mathrm{T}_{1}$ : Cross cultivation by cultivator, $\mathrm{T}_{2}:$ M.B.Plough + cultivator, $\mathrm{T}_{3}: 2 \mathrm{x}$ rotavator and $\mathrm{T}_{4}: 1 \mathrm{x}$ rotavator using a Randomized Block Design with five replications. The parameters evaluated were travel reduction (wheel slippage), draft, speed of operation, drawbar power, soil volume disturbed, fuel consumption, field efficiency and soil pulverization. Results indicated that single pass of rotavator $\left(\mathrm{T}_{4}\right)$ was economical as well as it performed satisfactory for seed bed preparation in comparison to the other treatments with respect to the parameters evaluated. The hourly cost required for tillage operation under $\mathrm{T}_{1}$ : Cross cultivation by cultivator, $\mathrm{T}_{2}:$ M.B. plough + cultivator, $\mathrm{T}_{3}: 2 \mathrm{x}$ rotavator and $\mathrm{T}_{4}: 1 \mathrm{x}$ rotavator was rupees 311.25 , $327.91,410.54$ and 280.17, respectively. The operational cost of single pass of rotavator $\left(\mathrm{T}_{4}\right)$ was observed lowest. So, amongst all implements used for seed bed preparation, the mini tractor drawn rotavator performed very well from the point of efficiency, soil pulverization and total hourly cost.

- KEY WORDS : Seed bed preparation, Fuel consumption, Draft, Wheel slip, Soil volume disturbed, Field efficiency, Soil pulverization

- HOW TO CITE THIS PAPER : Dabhi, K.L., Godhani, R.S. and Swarnkar, R. (2016). Comparative performance of mini tractor drawn tillage implements for seed bed preparation under sandy loam conditions of middle Gujarat. Internat. J. Agric. Engg., 9(1) : 53-61. 